\title{
Episodes in the Life of a Genius: J, Ernest Wilkins Jr.
}

\author{
Asamoah Nkwanta and Janet E. Barber
}

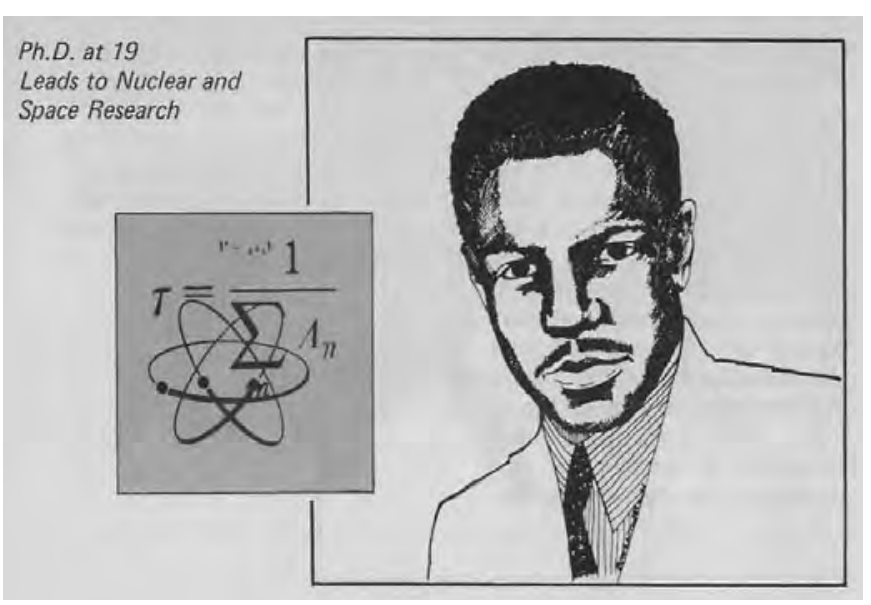

ABSTRACT. J. Ernest Wilkins Jr. had an IQ of 163 by age nine, earned a college degree at age sixteen, and received his doctorate in mathematics at age nineteen from the University of Chicago. This paper highlights his noteworthy contributions as a mathematician, physicist, engineer, and educator.
Asamoah Nkwanta is chair of the Department of Mathematics at Morgan State University. His email address is asamoah. nkwanta@morgan. edu. Janet E. Barber is chair of the School of Arts and Sciences at Stratford University, Alexandria, Virginia. Her email addresses are jbarber774@gmai 1. com and jabarber@ stratford. edu.

For permission to reprint this article, please contact:

reprint-permission@ams.org.

DOI: http://dx.doi.org/10.1090/noti1636

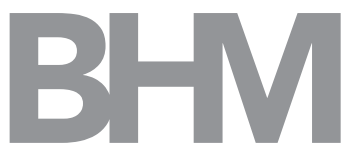

\section{Introduction}

By the age of nineteen, J. Ernest Wilkins Jr. had earned a doctorate in mathematics from the University of Chicago. Before being conferred with his $\mathrm{PhD}$, young Wilkins applied to the Institute for Advanced Study (IAS) in Princeton and was invited to become a member shortly thereafter. Over his career, this child prodigy and scientist made notable contributions to mathematics, physics, engineering, and education.

\section{Child Prodigy with a Big Bang IQ}

"One day, I'll fly to the moon with math." —Wilkins

In the 1930s Martin D. Jenkins [3], an educational psychologist (and president of Morgan State College, 1948-1970), conducted a study on highly intelligent African American children. Wilkins was classified a genius at age ten with an IQ of 163, surpassing the genius level of 150. Wilkins modestly informed Nkwanta that he was surely case no. 2 (see Table 1 ) and that he always wondered what happened to case no. 1, the young African American female genius with the IQ of 200.

Jenkins [3, p. 165] wrote:

Finally, these cases bring into sharp focus the limitations which our society places on the development of the highly gifted Negro. These children are nurtured in a culture in which racial inferiority of the Negro is a basic assumption. Consequently, they will experience throughout their lives, educational, social and occupational restrictions which inevitably affect achievement and motivation. ... Some of these individuals will meet frustration and draw away; others will go on to careers of high usefulness and accomplishment.

Though Wilkins was brilliant to genius level and many of his colleagues and mentors wrote letters of recommendation after his tenure with the Institute for Advanced 


\begin{tabular}{|c|c|c|c|c|c|c|}
\hline Case no. & Location & Age & S. Binet IQ & EQ (educ) & Grade & Race \\
\hline $\begin{array}{l}1 \text { Unknown } \\
\text { African American (F) }\end{array}$ & Chicago & $9-5$ & 200 & 158 & $5^{\text {th }}$ & $\mathrm{N}$ \\
\hline 2 J. Ernest Wilkins, Jr. (M) & Chicago & $10-6$ & 163 & 169 & $8^{\text {th }}$ & NWW \\
\hline $\begin{array}{l}3 \text { Unknown } \\
\text { African American (M) }\end{array}$ & Cincinnati & $6-9$ & 173 & 158 & $6^{\text {th }}$ & $\mathrm{N}$ \\
\hline $\begin{array}{l}4 \text { Unknown } \\
\text { African American (M) }\end{array}$ & Washington & $8-5$ & 163 & 169 & $6^{\text {th }}$ & NNW \\
\hline
\end{tabular}

Table 1. Wilkins's genius IQ of 163 appears in this edited chart entitled "Characteristics of 16 Negro Children of Binet IQ 150 and Above" from Martin D. Jenkins [3]. Under "Race," N denotes Negro, NWW denotes Negro with the possibility of white ancestry, and NNW denotes more Negro ancestry than white ancestry.

Study, research universities were unwilling to employ an African American. Therefore, most of Wilkins's active scientific career was with industry, the government, and academics working with Historically Black Colleges and Universities (HBCUs), such as Tuskegee, Howard, and Clark Atlanta.

As noted, Wilkins did experience his unfair share of racism and discrimination; however, he persevered. At age twenty, he worked on national projects, training and teaching pre-flight mathematics to hundreds of Tuskegee Airmen in the Army Air Force College Training Program. Between 1941 and 1945 Tuskegee Institute trained over 1,000 African American aviators for the war effort. As his career progressed, he received numerous honors for his work.

\section{Early Life of a Genius}

Wilkins's mother, Lucille B. Wilkins, was an educator who studied mathematics, and his father, J. Ernest Wilkins Sr., was an accomplished attorney, who graduated Phi Beta Kappa with a bachelor's degree in mathematics from the University of Illinois. Wilkins Sr. would eventually work for the White House during the Eisenhower administration. He was the first African American to participate in White House cabinet meetings. He served as assistant secretary of labor in 1954 and as a member of the Civil Rights Commission in 1958.

Wilkins Jr. was a child prodigy. At only a year old, he was able to recite the alphabet, and by the age of five he was able to add, subtract, multiply, and divide. He began school at the age of four. Coached at home by educated parents, Wilkins and his brothers were challenged with intellectual puzzles and math games. A high school teacher who recognized his talents and encouraged his mathematical genius enabled him to graduate from Parker High School in three years at age thirteen.

Wilkins gained fame upon entering the University of Chicago at age thirteen and becoming its youngest student. He participated in the William Lowell Putnam Mathematics Competition. He graduated Phi Beta Kappa at age sixteen in 1940. He completed his doctoral degree at age nineteen in 1942 with a dissertation titled "Multiple Integral Problems in Parametric Form in the Calculus of Variations," published in Annals of Mathematics (1944).

Prior to graduation, Wilkins penned a letter to the mathematician Oswald Veblen of the Institute for Advanced Study in Princeton, requesting permission to enroll there. Wilkins's Chicago dissertation advisor, Magnus Hestenes, followed up with a letter of support. In the letter, though he makes sure to inform Veblen that Wilkins is a good fellow and looks white, Hestenes also writes that "Mr. Wilkins is undoubtedly one of the best, if not the best, student [sic] we have had for a number of years." Wilkins received an offer and attended for three months, between 1942 and 1943. In a reply to Hestenes, Veblen indicated that Wilkins would be the second person of color to attend the Institute: "This year we have had another very good mathematician who came from the University of Illinois." The first African American member of the IAS was David H. Blackwell, who is the seventh African American to earn a PhD in mathematics, Wilkins the eighth. Veblen suggested that Wilkins write Blackwell to get suggestions for living arrangements in the Princeton area. Blackwell and Wilkins were contemporaries and attended many of the same mathematical conferences, meetings, and events in their future careers (see Figure 1).

While at the IAS, Wilkins was potentially exposed to the courses, works, and lectures of many internationally recognized mathematicians and physicists, such as Marston Morse, Hermann Weyl, Kurt Gödel, Wolfgang Pauli, Carl Ludwig Siegel, and Albert Einstein. Wilkins and Einstein were housed in the same office building. Wilkins wrote a letter, dated April 13, 1943, to Weyl indicating that he had taken courses in meromorphic functions by Weyl and algebraic geometry by Claude Chevalley. Wilkins wrote that he attended Solomon Lefschetz's seminar on non-linear differential equations and presented a report on a paper, 


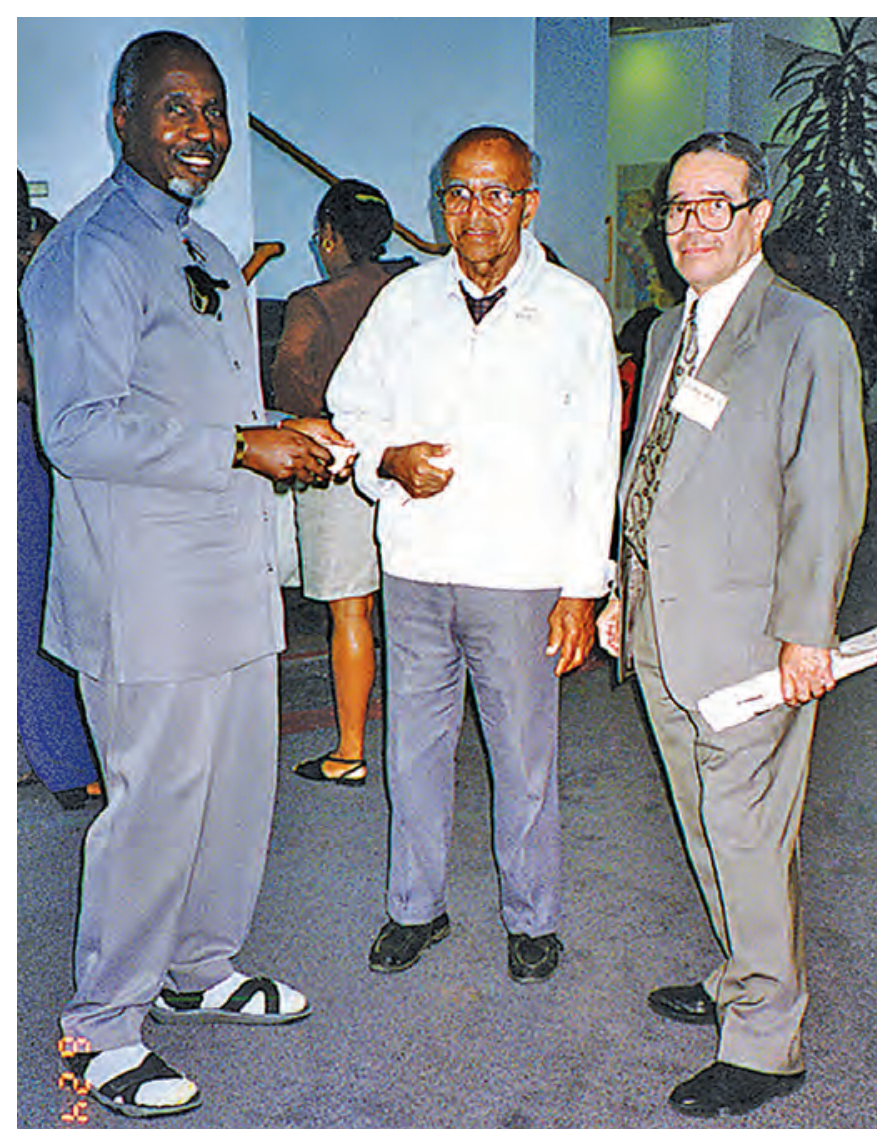

Figure 1. Abdulalim A. Shabazz, David H. Blackwell (the first African American member of the IAS), and Wilkins (the second), at the first CAARMS conference at MSRI in 1995.

"A General Equation for Relaxation Oscillations" by Norman Levison and Oliver K. Smith.

Wilkins later apparently requested a recommendation letter from one of his mathematics professors from Princeton University, IAS affiliate professor Lefschetz, when he was seeking an opportunity with the Navy Department. Lefschetz's letter, dated November 1, 1943, states that he had "formed the highest opinion of his capacity as a mathematician. He is exceptionally alert and hard working and I am certain would give you entire satisfaction in every way. I strongly recommend him."

Earlier 1943 letters disclosed that there was back-andforth correspondence between Wilkins and Morse. In one letter, Morse responded to Wilkins about information on local draft board forms and his position at Tuskegee Institute, as well as about work and education.

\section{The Teaching and Working Life of the Genius: Achievements, Honors, and Scientific Service}

Wilkins was a mathematics instructor at the Tuskegee Institute from 1943 to 1944, with work overlapping with industry. In 1944 he returned to the University of Chicago as associate mathematical physicist and as a physicist in its Metallurgical Laboratory, as part of the Manhattan Project, and discovered the Wilkins effect. He collaborated with the Nobel Prize-winning physicist Eugene Wigner on the Wigner-Wilkins Spectra, estimating the distribution of neutron energies within nuclear reactors.

Starting in 1950, Wilkins worked as a mathematician for the Nuclear Development Corporation of America. In 1956 he was elected Fellow of the American Association for the Advancement of Science and in 1964 Fellow of the American Nuclear Society. He was a visiting lecturer of the Mathematical Association of America from 1963 to 1967. During his remarkable career, Wilkins published many research papers and contributed to and solved many $M A A$ Monthly problems.

In 1970 Wilkins was invited by Warren Henry, a Tuskegee Institute and University of Chicago colleague, now a physics professor at Howard University, to come as a distinguished professor of applied mathematical physics. Wilkins accepted, helped establish the doctoral degree program in mathematics, and supervised four doctoral dissertations in physics.

Wilkins was president of the American Nuclear Society from 1974 to 1975 . Wilkins became the second African American to be elected to the National Academy of Engineering in 1976.

Wilkins was awarded an achievement medal in 1980 from the US Army for outstanding civilian services, the Quality Engineering for Minorities science award in 1994, and the National Association of Mathematicians (NAM) Lifetime Achievement Award also in 1994. The NAM inscription states:

In recognition of more than fifty professional years as a world class mathematician, physicist and engineer, gifted teacher and productive scholar it is NAM's distinct pleasure to name in your honor,

\section{THE J. ERNEST WILKINS JR. LECTURE}

To be given annually at the NAM undergraduate MATHFest conference and "Real Zeros of Random Polynomials," to be the inaugural J. Ernest Wilkins Jr. lecture.

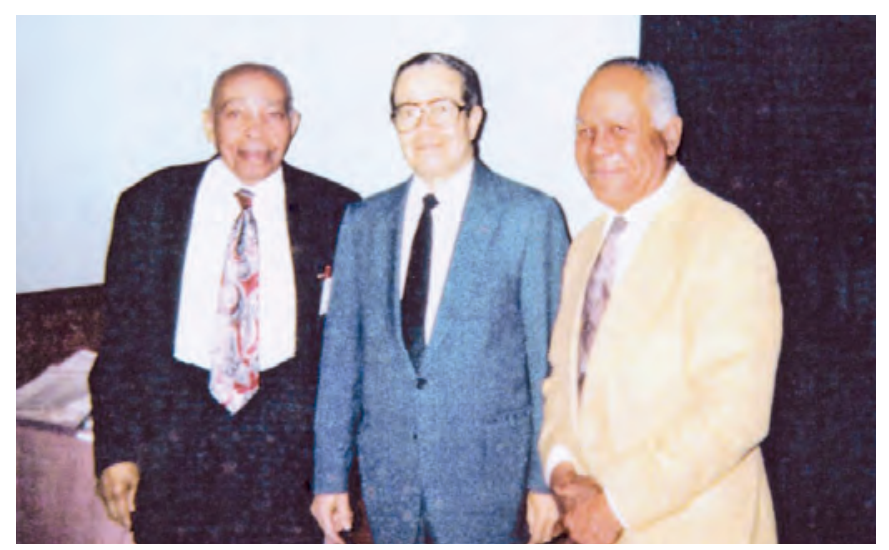

Figure 2. Warren E. Henry, Wilkins, and Henry McBay at the 1996 American Association for the Advancement of Science Meeting, Atlanta, GA. 


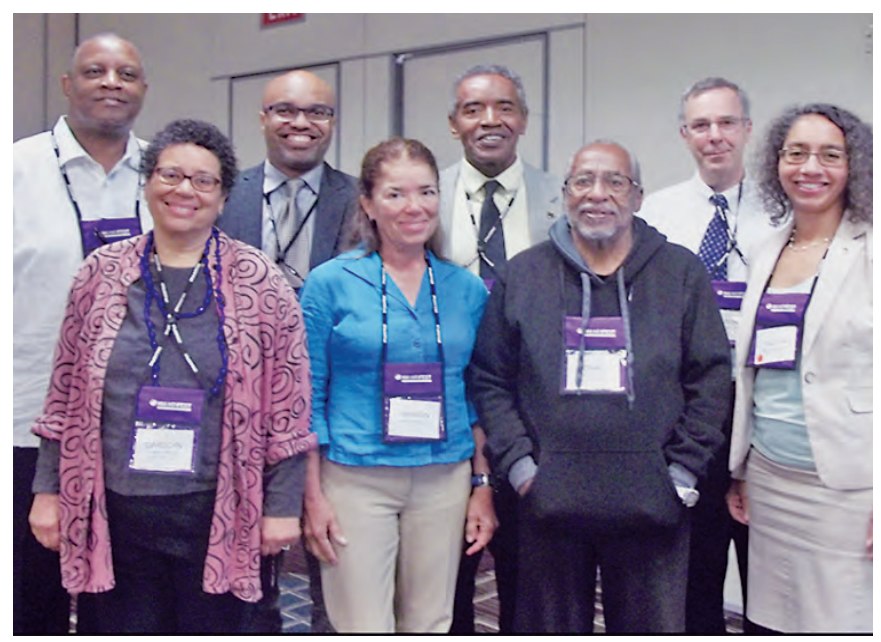

Figure 3. At "The Life and Legacy of J. Ernest Wilkins (1923-2011)," 2017 MathFest. Front row: niece Carolyn M. Wilkins, daughter Sharon Wilkins Hill, organizers Ronald E. Mickens and Talitha Washington. Back row: Nkwanta, organizer Ron Buckmire, former PhD student Cleo Bentley, Robert Fefferman.

Figure 2 shows Wilkins with two other icons in STEM, who were friends and contemporaries: Warren Henry and Henry McBay.

In 1996, Wilkins received the special recognition award from the US Department of Energy. A year later in 1997, he received a Professional Achievement Citation from the University of Chicago Alumni Association. In 2007 he was honored yet again at the University of Chicago in a special ceremony dedicating his portrait and plaque for display in the Eckhart Hall Tea Room.

The 2017 MAA MathFest held a special session on "The Life and Legacy of J. Ernest Wilkins (1923-2011)" (Figure 3). This session shared his impact in nuclear-reactor physics and optics, his plight of being a genius of color, and his admirable influence on the mathematical community.

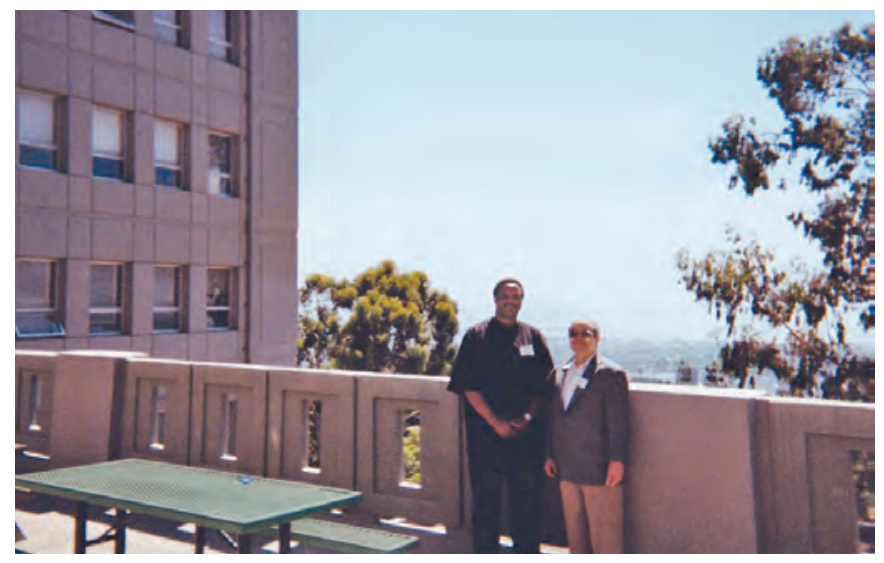

Figure 4. Wilkins with Nkwanta at CAARMS 10 at Lawrence Berkeley National Lab, California, 2004.

\section{References}

[1] N. Agwu, A. NkwAnTA, DR. J. ERnEST Wilkins, JR.: The Man and His Works, DIMACS Series in Discrete Mathematics and Theoretical Computer Science, Amer. Math. Soc. 34 (1997), 194-205.

[2] Institute for Advanced Study (IAS). The Shelby White and Leon Levy Archives Center, Princeton, NJ. Director's Office Member Files for: J. Ernest Wilkins Jr.

[3] M. JENKINS, Case Studies of Negro Children of Binet IQ 160 and Above, The Journal of Negro Education 12 (1943), 159-166.

[4] A. NKWANTA AND J. BARBER, African American Mathematicians and the Mathematical Association of America, MAA Centennial, Historical Articles (July 2015), https://www . maa.org/sites/defau1t/files/pdf/centennial/African_Americans.pdf

[5] C. M. WILKINS, Damn Near White: An African American Family's Rise from Slavery to Bittersweet Success, University of Missouri Press, Columbia and London (2010).

\section{Photo Credits}

Illustration of J. Ernest Wilkins is in the public domain.

Figure 1 courtesy of Raymond L. Johnson.

Figure 2 courtesy of Ronald E. Mickens.

Figure 3 courtesy of Cleo Bentley.

Figure 4 courtesy of Asamoah Nkwanta.

Photo of Asamoah Nkwanta courtesy of Charlita Woodruff-White. Photo of Janet E. Barber courtesy of Janet Barber.

\section{ABOUT THE AUTHORS}

Asamoah Nkwanta encountered Wilkins while an undergraduate at North Carolina Central University in the book Black Mathematicians and Their Works, while a graduate student at Howard University at the Institute on the History of Mathematics and its Use in Teaching workshop, and as a professor and research mathematician at several CAARMS conferences.

Janet E. Barber is a behavioral scientist, sociologist, editor, and writer, who collaborates and works with Nkwanta. Their many research collaborations began at North Carolina Central and Morgan State Universities. Her research and writing involve the study of positive psychology, critical thinking, cultural diversity, and leadership.

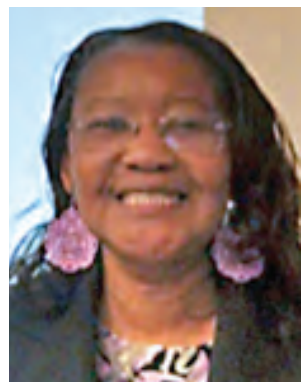

Janet E. Barber

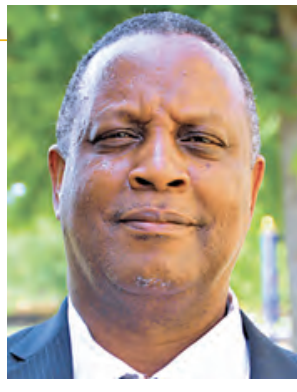

Asamoah Nkwanta 